\title{
Determination of Sulfamethoxazole in Pharmaceutical Formulations by Flow Injection System/HPLC with Potentiometric Detection using Polypyrrole Electrode
}

\author{
Sabriye P. Ozkorucuklu, *,a Yucel Sahin ${ }^{b}$ and Guleren Alsancak ${ }^{a}$ \\ ${ }^{a}$ Department of Chemistry, Faculty of Arts and Sciences, Süleyman Demirel University, \\ 32260 Isparta, Turkey \\ ${ }^{b}$ Department of Chemistry, Faculty of Science, Anadolu University, 26470 Eskişehir, Turkey
}

\begin{abstract}
Neste trabalho, um eletrodo de polipirrol (PPy) foi utilizado como detector eletroquímico potenciométrico em um sistema de injeção em fluxo para a determinação de sulfametoxazol em formulações farmacêuticas. O eletrodo PPy foi preparado por voltametria cíclica em solução de acetonitrila. Uma relação linear foi observada no intervalo de concentração de $2,5 \times 10^{-5}$ a $1,25 \times 10^{-3} \mathrm{~mol} \mathrm{~L}^{-1}$ com um coeficiente de correlação de 0,9977 e limite de detecção de $1,03 \times 10^{-6} \mathrm{~mol} \mathrm{~L}^{-1}$ $(\mathrm{S} / \mathrm{N}=3)$. As recuperações em cápsulas e xaropes foram 97,4 e 90,8\% com desvios padrões relativos de 0,62 e 1,04\%, respectivamente, concordando com valores obtidos por cromatografia líquida de alto rendimento (HPLC) com detector de UV. Então, concluiu-se que o eletrodo PPy pode ser usado como material detector potenciométrico alternativo para a determinação de sulfametoxazol em formulações farmacêuticas com as vantagens de fácil preparação e capacidade de regeneração da superfície do eletrodo.
\end{abstract}

In this work, it was used a polypyrrole (PPy) electrode as a potentiometric electrochemical detector in a flow injection system in order to determine sulfamethoxazole in pharmaceutical formulations. The PPy electrode was prepared by cyclic voltammetry in acetonitrile solution. A linear relationship was observed over the concentration range of $2.5 \times 10^{-5}-1.25 \times 10^{-3} \mathrm{~mol} \mathrm{~L}^{-1}$ with a correlation coefficient of 0.9977 and limit of detection (LOD) of $1.03 \times 10^{-6} \mathrm{~mol} \mathrm{~L}^{-1}(\mathrm{~S} / \mathrm{N}=3)$. The recoveries in tablet and syrup formulations were found as 97.4 and $90.8 \%$ with the relative standard deviations of 0.62 and $1.04 \%$, respectively, which closely agree with those measured by high performance liquid chromatography (HPLC) with UV detector. Therefore, it was concluded that the PPy electrode can be used as an alternative novel potentiometric detector material for determination of sulfamethoxazole in pharmaceuticals with the advantages of easy preparation and regeneration capability of the electrode surface.

Keywords: sulfamethoxazole, potentiometric detection, flow injection system, HPLC, pharmaceuticals

\section{Introduction}

In recent years, the research activities on the potentiometric sensor with nanomolar or subnanomolar detection limits in the literature have increased. ${ }^{1,2}$ Bakker and Pretsch ${ }^{3}$ reviewed recent progress in the development and application of potentiometric sensors. Rubinova et al. ${ }^{4}$ used a potentiometric sensor based on polymer membranes with a limit of detection (LOD) of nanomolar range. Szigeti et al. ${ }^{5}$ reported a novel potentiometric and optical sensors for silver ion also with a limit of detection of subnanomolar.

*e-mail: sabriyeozkorucuklu@sdu.edu.tr
A potentiometric detector that is based on membrane electrodes offers an attractive alternative in high performance liquid chromatography (HPLC) and capillary electrophoresis (CE) for determination of organic cations. ${ }^{6-10}$ The effect of matrix interference for UV-absorbing compounds which are early eluted from HPLC columns ${ }^{11}$ can be strongly reduced by the application of potentiometric detection. ${ }^{6,7}$ The potentiometric detection is not restricted to electroactive compounds, comparing to amperometric detectors, and also does not need ion suppressor system, the case for conductometric detection. ${ }^{12}$ Moreover, in contrast to amperometric detectors, ${ }^{13,14}$ the response of potentiometric detector is quasi-independent 
on a flow rate which creates possibilities for the use in miniaturized systems, ${ }^{6}$ as well as in turbulent or ultrahigh flow rates in HPLC system. These last flow rates are currently recommended due to the effective decrease in the analysis of the sample cycle time. ${ }^{15}$

The field of polymer-modified electrodes (PMEs) has received rather extensive interest from analytical chemistry. These electrodes generally consist of polymer layer that is attached to an electrode surface to improve selectivity and sensitivity. Intrinsic conducting polymers with conjugated double bonds have attracted much attention as advanced materials. Among those conducting polymers, polypyrrole (PPy) is especially promising for commercial applications because of its good environmental stability, facile synthesis and higher conductivity than many other conducting polymers. PPy can be easily prepared from aqueous and organic solvent by either chemical or electrochemical oxidative polymerization of pyrrole, and the electrochemical polymerization is simple and rapid. In recent years, electropolymerized PPy films have been used to modify electrode surfaces for potentiometric sensors and ion-selective electrodes. ${ }^{16,17}$

Sulfamethoxazole (SMX) is a 4-amino- $N$-(5-methly3-isoxazolyl) benzenesulfonamide (Figure 1) and its action is primarily bacteriostatic. Although SMX may be bactericidal where concentrations of thymine are low in the surrounding medium. The sulfonamides have a broad spectrum of action, but the development of widespread resistance has greatly reduced their usefulness, and often the susceptibility widely varies even among nominally sensitive pathogens.

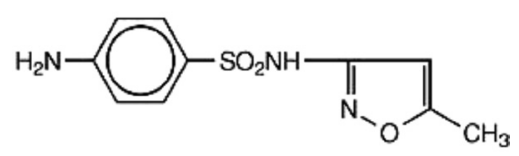

Figure 1. The chemical structure of sulfamethoxazole.

HPLC with UV or fluorometry detector is a common method for determining the sulfa drugs. ${ }^{18-24}$ An alternative method for determination of these sulfonamides is HPLC with an electrochemical detector (HPLC-ED) using the amperometric technique. Klimes and Mokry Rao ${ }^{25}$ carried out analysis for four sulfonamides (sulfamethoxazole, sulfamoxazole, sulfisoxazole and sulfamethoxydiazine) by HPLC with electrochemical detector using a glassy carbon electrode. Rao et.al. ${ }^{26}$ and Preechaworapun et.al. ${ }^{27}$ investigated electrochemical behaviors of sulfonamides using cyclic voltammetry at a boron-doped diamond electrode (BDD). The results obtained with the BDD electrode were used for determination of those compounds with HPLC utilizing the BDD electrode as an amperometric detector. Although HPLC and flow injection analysis methods using coated electrodes with conducting polymers as amperometric detector have been reported for determination of some organic and biological molecules, ${ }^{28-30}$ limited information is available about the use of conducting polymers as a potentiometric detector. ${ }^{31}$ However, to the best of our knowledge this is the first time that the PPy potentiometric detector in HPLC for determination of sulfamethoxazole is reported. The PPy film was electrochemically deposited onto glassy carbon electrode. The PPy electrode was successfully applied as a potentiometric detector for fast and accurate determination of sulfamethoxazole in standards and pharmaceutical samples.

\section{Experimental}

\section{Chemicals and reagents}

Sulfamethoxazole (99.9\%) was obtained from SigmaAldrich (Germany). Acetonitrile (99.9\%, Sigma-Aldrich, Germany), tetrabutylammonium perchlorate (TBAP, 99\%, Fluka, Germany), sodium hydroxide (98\%, Merck, Germany), potassium hydrogen phthalate (99.5\%, Merck, Germany, dried at $110{ }^{\circ} \mathrm{C}$ before use), phosphoric acid (85\%, Riedel-de Haen, Germany), acetic acid (Glacial, Riedel-de Haen, Germany), boric acid (99.5\%, Carlo Erba, Italy) are available commercially as analytical grade reagents. Pyrrole (98\%, Aldrich, Germany) was repeatedly distilled under vacuum until a colorless liquid was obtained and kept under nitrogen in darkness at $4{ }^{\circ} \mathrm{C}$. All aqueous solutions were prepared with ultra-pure deionized water (Sartorius). Trimoks Fort tablet (Atabay) and Bactrim syrup (Roche) were purchased from local pharmacy. Freshly prepared solution of sulfamethoxazole was prepared each day owing to its low stability.

\section{Instrumentation}

Electrochemical studies were performed using Autolab PGSTAT 100 potentiostat-galvanostat controlled by GPES 4.9 software (Ecochemie, The Netherlands). Three electrode system was used for all measurements: a glassy carbon (GC, $3 \mathrm{~mm}$ diameter) as the indicator and a $\mathrm{Pt}$ auxiliary electrode. All measurements were carried out with an $\mathrm{Ag} / \mathrm{AgCl}$ reference electrode. Prior to modification, the GC electrode (1 mm diameter, 99.99\%, Aldrich) was polished with an aqueous suspension of 0.05 microns gamma alumina powder (CH Instruments, Inc.). After each polishing, the electrode was washed with acetonitrile and after that, dried. 
Chromatographic measurements were carried out using a Dionex P680 pump (Dionex) and an YMC Pack ODS-AM $(5 \mu \mathrm{m}, 250 \mathrm{~mm} \times 4.6 \mathrm{~mm}$ ID) end-capped column and an LC-4C electrochemical system (BAS). The used eluent was a buffer solution of Britton-Robinson (BR), prepared in $50 \%(\mathrm{v} / \mathrm{v})$ acetonitrile-water binary mixtures at $\mathrm{pH} 2.5$, for determination of sulfamethoxazole. The eluent was filtered through a $0.45 \mu \mathrm{m}$ syringe type filter (Millipore), and then degassed for $15 \mathrm{~min}$. The $\mathrm{pH}$ of eluent was measured using the MA 235 model (Mettler Toledo, Switzerland) pH-Ion meter with InLab $416 \mathrm{Ag} / \mathrm{AgCl}$ glass electrode was used for $\mathrm{pH}$ measurements. In order to validate the potentiometric detection, the pharmaceutical samples were also determined by a HPLC with UV-Visible detector (Agilent 1110 series). The flow rate of the eluent was $1 \mathrm{~mL} \mathrm{~min}^{-1}$. The potentiometric measurements were carried out by an electrochemical cell (LC-4C radial flow cell, BAS) with a PPy coated glassy carbon (GC) electrode and an $\mathrm{Ag} / \mathrm{AgCl}$ reference electrode. The flow cell was maintained at room temperature $\left(25 \pm 1^{\circ} \mathrm{C}\right)$ during all the measurements.

\section{Preparation of polypyrrole potentiometric detector}

PPy was obtained in a conventional one-compartment three-electrode cell by electrodeposition on the surface of GC using cyclic voltammetry in the potential range between -0.60 to $+1.40 \mathrm{~V}$ during five cycles (scan rate of $100 \mathrm{mV} \mathrm{s}^{-1}$ ) in $0.1 \mathrm{~mol} \mathrm{~L}^{-1}$ pyrrole and $0.1 \mathrm{~mol} \mathrm{~L}^{-1}$ TBAP/acetonitrile solution. After the electropolymerization process, the PPy electrodes were washed with acetonitrile to remove the excess pyrrole and TBAP. The PPy electrodes were dried at room temperature before the experiments. When the coated electrodes were not in use, they were stored in $1.0 \times 10^{-3} \mathrm{~mol} \mathrm{~L}^{-1} \mathrm{TBAP}$ at room temperature.

\section{Preparation of solutions}

A stock eluent (BR buffer) solution that was composed of a mixture of boric, acetic $\left(0.04 \mathrm{~mol} \mathrm{~L}^{-1}\right)$ and phosphoric acids $\left(0.04 \mathrm{~mol} \mathrm{~L}^{-1}\right)$ was prepared and its $\mathrm{pH}$ values were adjusted by the addition of $1.0 \mathrm{~mol} \mathrm{~L}^{-1} \mathrm{NaOH}$. The $\mathrm{pH}$ meter was calibrated in the acetonitrile-water solution with different hydro-organic mixtures potassium hydrogenphthalate buffers $\left(0.05 \mathrm{~mol} \mathrm{~kg}^{-1}\right)$. $^{32}$ The standard stock solution of sulfamethoxazole $\left(0.01 \mathrm{~mol} \mathrm{~L}^{-1}\right)$ was obtained by dissolving $0.0253 \mathrm{~g}$ of sulfamethoxazole in a $10 \mathrm{~mL}$ volumetric flask for each acetonitrile-water mixture. The stock standard was stored at $4{ }^{\circ} \mathrm{C}$.

Various commercial pharmaceutical tablets and syrup having sulfamethoxazole were examined for estimation of SMX. The tablets were grounded to powder and then dissolved in 50\% acetonitrile-water mixture. The solution was sonicated for $10 \mathrm{~min}$ and filtered. An aliquot of appropriate volume of stock solution was transferred into $250 \mathrm{~mL}$ volumetric flask. The syrup was transferred to a $100 \mathrm{~mL}$ flask. Both flasks were completed with BR buffer (50\% acetonitrile-water mixture, $\mathrm{pH} 2.5$ ). All the samples were further diluted to achieve the concentration of SMX in the working range. The samples were then spiked with appropriate amount of SMX for the experiments.

\section{Results and Discussion}

\section{Electrochemical preparation of polypyrrole}

The PPy film was prepared by electropolymerization of pyrrole on GC electrode. The oxidation peak corresponds to the formation of pyrrole radical cations. The formation and growth of the polymer film can be easily seen in Figure 2. The peaks that are due to the oxidation and reduction of the film increase in intensity as the film grows. A broad oxidation peak was observed at the peak potential of $+0.25 \mathrm{~V}$ and the reverse cathodic peak was seen at the peak potential of $+0.15 \mathrm{~V}$. The cyclic voltammetry is a simple and rapid technique of controlling the thickness of the conductive polymer film.

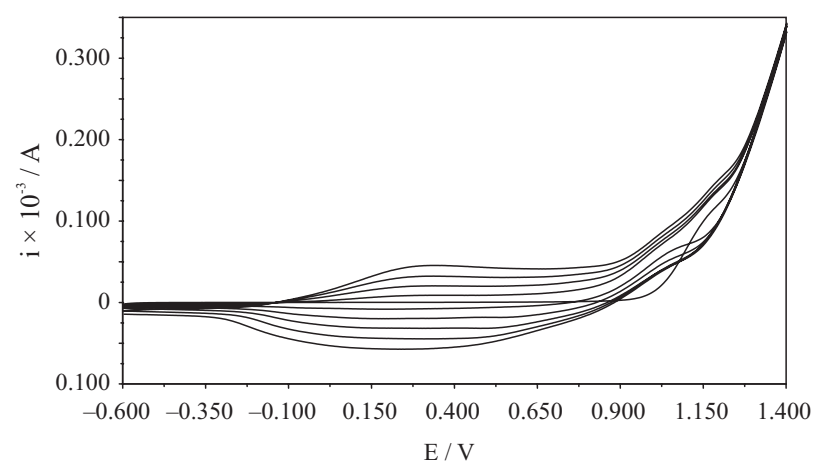

Figure 2. Multisweep cyclic voltammograms taken during the electropolymerization of pyrrole $\left(0.1 \mathrm{~mol} \mathrm{~L}^{-1}\right)$ into a glassy carbon electrode (scan rate of $100 \mathrm{mV} \mathrm{s}^{-1}$, supporting electrolyte of $0.1 \mathrm{~mol} \mathrm{~L}^{-1}$ TBAP and number of scans of 5).

The electrochemical behavior of the PPy film was studied by potential cycling between -0.60 and $+1.00 \mathrm{~V}$ (vs. Ag/AgCl) in monomer free solution (acetonitrile solution of $0.1 \mathrm{~mol} \mathrm{~L}^{-1} \mathrm{TBAP}$ ) (not given here). A broad oxidation peak was observed at the potential of +0.20 and reverse cathodic peaks were seen at the peak potential of $0.00 \mathrm{~V}$.

\section{Method development}

The selection of an eluent is important for the successful determination of an analyte using potentiometric detection in 
HPLC method. BR buffer solution was used as an eluent for determination of SMX at the PPy electrode in acetonitrilewater binary mixtures. The strength of the detector response is based upon the selectivity of the PPy electrode between the eluent and analyte in the chromatographic system. No response was established for the eluent by using PPy electrode as a potentiometric detector. The baseline of the chromatogram was not changed during the analysis.

To determine the effect of the eluent system to SMX, the eluent solutions were prepared in varying acetonitrile-water ratios in the range of $15-50 \%(\mathrm{v} / \mathrm{v})$ at $\mathrm{pH}$ value from 1.5 to 7.0. Figure 3 shows the results of such comparison. The potentiometric response of the PPy electrode to SMX increased with the $\mathrm{pH}$ increase of the eluent solution up to 2.5. There was considerable decrease in the response of the PPy electrode below and above this $\mathrm{pH}$ value. In addition, as the acetonitrile-water ratios increased in the eluent solution, the obtained response to SMX of the PPy electrode was also increased. The highest potentiometric response for SMX was obtained by using BR buffer solutions that were prepared in acetonitrile-water binary mixture $(50 \%(\mathrm{v} / \mathrm{v}))$ at $\mathrm{pH}$ 2.5. The results are summarized in Table 1.

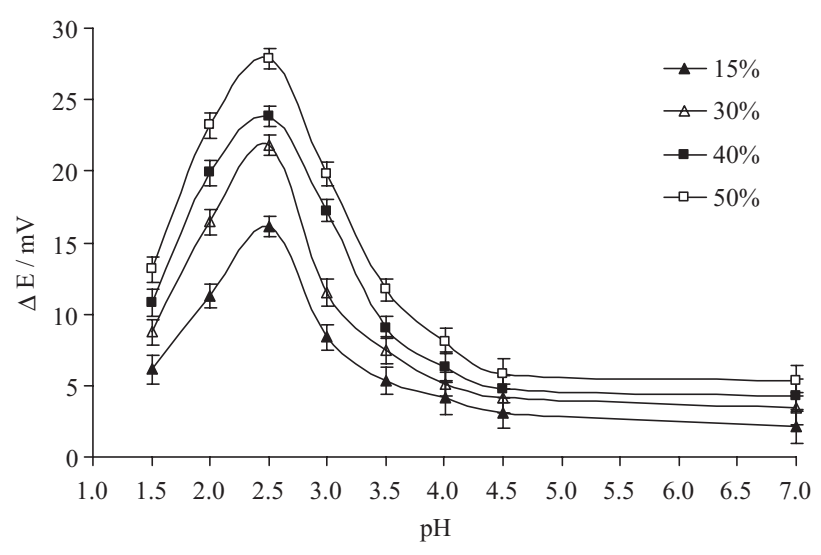

Figure 3. The effects of acetonitrile-water ratio and $\mathrm{pH}$ of the solution on the chromatographic response of PPy detector for $1.0 \times 10^{-4} \mathrm{~mol} \mathrm{~L}^{-1}$ sulfamethoxazole in Britton-Robinson buffer solutions.
The $\mathrm{pK}_{\mathrm{a} 1}$ values for the sulfonamides are between 2.8 and 3.0, 50 at.\% (v/v) acetonitrile-water binary mixtures. ${ }^{33}$ Since the $\mathrm{pH}$ value of the media is lower than $\mathrm{pK}_{\mathrm{a} 1}$ value of the sulfonamides, the sulfonamides are present in cationic form, where the maximum oxidation current was observed at $\mathrm{pH} 2.5$ and 3.0. There may be an electrostatic interaction between the oxygen atom in the $\mathrm{O}=\mathrm{S}=\mathrm{O}$ group of $\mathrm{SMX}$ and the hydrogen atom of the $\mathrm{N}-\mathrm{H}$ group of pyrrole units.

The detector behavior was influenced by the employed flow-rate in the separation process. The retention time, resolution, response, analysis time and column pressure were affected by flow-rate. Experiment results showed that the retention time, resolution, analysis time and responses of SMX were found to decrease with the increase of the flow-rate from 0.25 to $2.0 \mathrm{~mL} \mathrm{~min}^{-1}$. However, the column back pressure dramatically increased. It was necessary to select an appropriate flow-rate to improve the chromatograms of SMX. Therefore, the optimum

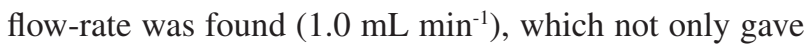
a satisfactory sensitivity for the analysis, but also induced a relatively low backpressure on the column.

\section{Effect of the electropolymerization cycles}

The number of electropolymerization cycle has a significant influence on the potentiometric response performance of PPy. The optimum number of cycles to form the sensing layer of the electrode was determined from a series of experiments in which PPy films were fabricated at different numbers of cycles between 2 and 10 (Figure 4). As the electropolymerization cycle increased, the obtained response of the PPy electrode was also higher. A thicker PPy film was generated using long cycle. However, this process may cause decrease in the sensitivity of the electrode. Because of this limitation, a greater number of cavities will permit a greater diffusion of SMX to the active surface of the electrode. The response of the PPy

Table 1. The peak heights and relative standard deviations (RSD) of SMX by PPy-potentiometric detector in different acetonitrile (ACN)-water binary mixture between $\mathrm{pH}$ of 1.5-7.0

\begin{tabular}{lcccc}
\hline $\mathrm{pH}$ & $\begin{array}{c}15 \% \\
\mathrm{E} / \mathrm{mV}(\mathrm{RSD} / \%)\end{array}$ & $\begin{array}{c}30 \% \\
\mathrm{E} / \mathrm{mV}(\mathrm{RSD} / \%)\end{array}$ & $\begin{array}{c}40 \% \\
\mathrm{E} / \mathrm{mV}(\mathrm{RSD} / \%)\end{array}$ & $\begin{array}{c}50 \% \\
\mathrm{E} / \mathrm{mV}(\mathrm{RSD} / \%)\end{array}$ \\
\hline 1.5 & $6.125(1.04)$ & $8.720(0.87)$ & $10.74(0.94)$ & $13.14(0.91)$ \\
2.0 & $11.12(0.82)$ & $16.455(0.87)$ & $19.87(0.86)$ & $23.22(0.89)$ \\
2.5 & $16.12(0.71)$ & $21.78(0.73)$ & $23.84(0.73)$ & $27.89(0.72)$ \\
3.0 & $8.362(0.89)$ & $11.52(0.97)$ & $17.25(0.80)$ & $19.81(0.78)$ \\
3.5 & $3.384(0.94)$ & $7.470(0.96)$ & $9.057(0.80)$ & $11.74(0.74)$ \\
4.0 & $4.150(1.13)$ & $5.125(0.82)$ & $6.295(1.10)$ & $8.025(0.88)$ \\
4.5 & $3.085(1.07)$ & $4.115(0.98)$ & $4.735(0.93)$ & $5.860(1.07)$ \\
7.0 & $2.117(1.22)$ & $3.414(1.10)$ & $4.307(1.12)$ & $5.305(1.05)$ \\
\hline
\end{tabular}


electrode to SMX was found to increase with the increase of the electropolymerization cycles up to 5 . There was a small decrease in the response of PPy detector above this number of cycles. In this study, taking into consideration the stability of PPy detector, peak height and reproducibility of the results, the PPy films were electropolymerized on the $\mathrm{GC}$ electrode in the potential range between -0.60 and $1.40 \mathrm{~V}$ during five cycles from a solution of $0.1 \mathrm{~mol} \mathrm{~L}^{-1}$ pyrrole and $0.1 \mathrm{~mol} \mathrm{~L}^{-1} \mathrm{TBAP}$ in acetonitrile.

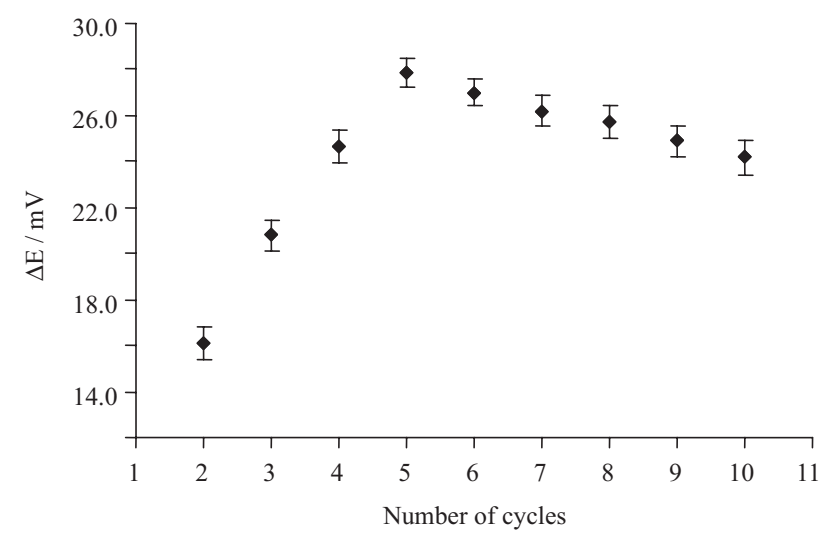

Figure 4. Effect of the number of cycles on the chromatographic response of PPy detector for $1.0 \times 10^{-4} \mathrm{~mol} \mathrm{~L}^{-1}$ sulfamethoxazole in $50 \%(\mathrm{v} / \mathrm{v})$ acetonitrile-water Britton-Robinson buffer at $\mathrm{pH} 2.5$.

\section{Chromatographic behavior of sulfamethoxazole}

When BR buffer solution in 50\% (v/v) acetonitrilewater at $\mathrm{pH} 2.5$ was used as the mobile phase, the retention time of $3.50 \mathrm{~min}$ was obtained for SMX $\left(1.0 \times 10^{-4} \mathrm{~mol} \mathrm{~L}^{-1}\right)$ by HPLC with PPy potentiometric detector. As shown in Figure 5, the substance was eluted, forming well shaped and symmetrical single peak, being well separated from the solvent front. The baseline of the chromatogram was directly given without making any correction in this figure to show the actual chromatograms.

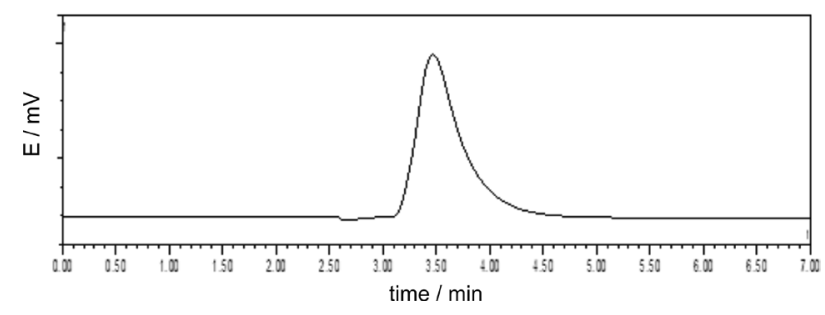

Figure 5. Chromatogram of $1.0 \times 10^{-4} \mathrm{~mol} \mathrm{~L}^{-1}$ sulfamethoxazole with polypyrrole potentiometric detector.

An electrical potential difference is established when a permselective film separates two ionic solutions. A permselective film permits only charged ions to permeate. The response mechanisms describing ion transport or displacement over films are mostly obscure. When films are coated onto a solid electrode material (this is the case in our study (GC)), it would be indeed difficult to describe potentials as being produced by diffusion of the analyte from one side of the film to the other. A phenomenon that occurs at the film-solution interface would give a more acceptable explanation for the observed potentials. The driving forces behind the potentiometric responses are mostly analogous, i.e. differences in the analyte concentration between the solution and the interior of the film.

The stock solution of SMX was prepared by dissolving the standards in acetonitrile. Then, the stock solution was diluted to known concentrations in the range between $2.5 \times 10^{-5}-1.25 \times 10^{-3} \mathrm{~mol} \mathrm{~L}^{-1}$. These were injected into HPLC and four replicate injections were performed in each case. A series of chromatograms was recorded at various concentrations of SMX $\left(2.5 \times 10^{-5}-1.25 \times 10^{-3} \mathrm{~mol} \mathrm{~L}^{-1}\right)$ to determine the calibration curve. When the SMX concentration was higher than $1.25 \times 10^{-3} \mathrm{~mol} \mathrm{~L}^{-1}$, the peak height has almost no change. The calibration curve was obtained by measuring the peak potentials $(\mathrm{mV}) v s$. the concentration of SMX $\left(\mathrm{mol} \mathrm{L}^{-1}\right)$, shown in Figure 6. The calibration data were fitted and the slope, intercept and coefficient of graphs were calculated. Table 2 represents the calibration characteristics and related parameters for SMX using PPy potentiometric detector.

Table 2. Characteristics of sulfamethoxazole calibration plots using the proposed method

\begin{tabular}{lc}
\hline & Sulfamethoxazole \\
\hline Linearity range / $\left(\mathrm{mol} \mathrm{L}^{-1}\right)$ & $2.5 \times 10^{-5}-1.25 \times 10^{-3}$ \\
Slope & 4.4761 \\
Intercept & $5.0 \times 10^{-4}$ \\
Correlation coefficient & 0.9977 \\
RSD of slope & 0.81 \\
RSD of intercept & 1.02 \\
LOD / (mol L & -1) \\
LOQ / $\left(\mathrm{mol} \mathrm{L}^{-1}\right)$ & $1.03 \times 10^{-6}$ \\
\hline
\end{tabular}

RSD: relative standard deviations.

The calibration curve had good linearity with correlation coefficient of 0.9977. The limit of detection (LOD) and limit of quantification (LOQ) of sulfamethoxazole were calculated according to the formula $3 \mathrm{~s} / \mathrm{m}$ and $10 \mathrm{~s} / \mathrm{m}$ criteria, respectively, where $m$ is the slope of the calibration graph and $s$ is the standard deviation of the blank signal. The results are also shown in Table 2. The LOD and LOQ values obtained by HPLC with PPy-potentiometric detector method are lower than that reported in the literature using HPLC with UV detection. ${ }^{20}$ The response of SMX at PPy 


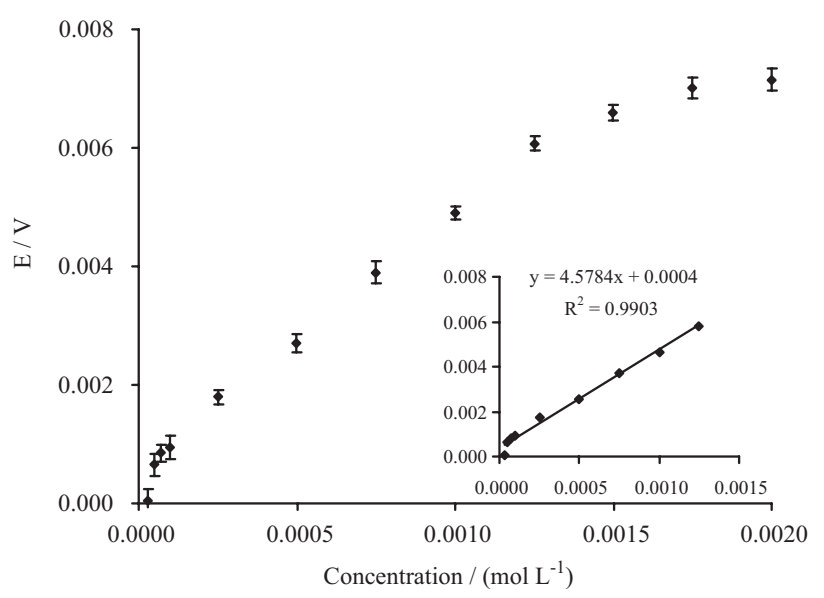

Figure 6. The calibration curve of SMX between the peak potentials and concentration of sulfamethoxazole.

electrode maintained over $92 \%$ of the original value for 15 days. There was no evidence of retention time, chemical and mechanical deterioration during the above period of operation.

\section{Analytical application to pharmaceutical formulations}

The proposed method was applied to the determination of SMX in a commercial tablet and syrup samples. The obtained solution by dissolution of SMX was subsequently diluted, so that sulfamethoxazole concentration lies in the range of the calibration plots at the optimal conditions. The samples were analyzed according to the specified chromatographic conditions. No interfering substance could be noticed in tablet and syrup. In order to validate the potentiometric detection, SMX tablet was also determined by a HPLC method with UV detection. Table 3 shows the obtained data when the PPy potentiometric and UV detectors are used in HPLC. Each value in this table is the mean of the four consecutive measurements. The results reveal that both methods had adequate precision and accuracy. Therefore, both of them can be applied to the determination of SMX in pharmaceutical formulations.

Student $t$-test and $F$-test were carried out on the data to statistically examine the validity of the obtained results. At 95\% confidence level, the calculated $t$ and $F$ values were less than that of theoretical $t$ and $F$ values. The results showed that there was no significant difference between the proposed and HPLC-UV method. In Table 3, it is possible to observe that both detection methods were useful for analytical purposes.

\section{Conclusions}

In this study, the PPy electrode was successfully applied as a sensitive potentiometric detector in HPLC for fast and accurate determination of sulfamethoxazole in some pharmaceutical formulations. The PPy potentiometric detector showed a stable and reproducible response without any influence of interferents existing in eluent and pharmaceutical samples. Using PPy electrode as a potentiometric detector a well-shaped, well-separated from the solvent front and symmetrical single peak was obtained for SMX without any response for eluent. The PPy electrode could be used for 15 days. The detector showed good activity towards the determination of SMX with wide linear concentration range. The recoveries in tablet and syrup were found as 97.4 and $90.8 \%$ with the relative standard deviations of 0.62 and $1.04 \%$, respectively. The determined SMX concentrations using these methods are in good agreement with declared values. Additionally, the results of recovery are lower than that reported in the literature with differential pulse voltammetry method using molecularly imprinted polymer based sensor. ${ }^{34}$ It is concluded that this electrode can be used as an alternative potentiometric detector material for determination of SMX in standards and pharmaceutical preparations.

Table 3. Comparative studies for determination of sulfamethoxazole in pharmaceutical formulations

\begin{tabular}{lcccc}
\hline & \multicolumn{2}{c}{ PPy potentiometric detector } & \multicolumn{2}{c}{ UV dedector } \\
\cline { 2 - 5 } & $\begin{array}{c}\text { Trimoks Fort tablet } \\
\text { (Atabay) }\end{array}$ & $\begin{array}{c}\text { Bactrim syrup } \\
\text { (Roche) }\end{array}$ & $\begin{array}{c}\text { Trimoks Fort tablet } \\
\text { (Atabay) }\end{array}$ & $\begin{array}{c}\text { Bactrim syrup } \\
\text { (Roche) }\end{array}$ \\
\hline Reported content & $0.500^{\mathrm{a}}$ & $50^{\mathrm{b}}$ & $0.500^{\mathrm{a}}$ & $50^{\mathrm{b}}$ \\
Detected content & $0.487^{\mathrm{a}}$ & $45.4^{\mathrm{b}}$ & $0.491^{\mathrm{a}}$ & $47.4^{\mathrm{b}}$ \\
Recovery / \% & 97.4 & 90.8 & 98.2 & 94.8 \\
RSD / \% & 0.62 & 1.04 & 0.78 & 0.76 \\
Student $t$-test & 0.12 & 0.29 & 0.52 & 0.16 \\
$F$-test & 1.89 & 1.72 & $t_{\text {theoretical }}: 2.31$ & $F_{\text {theoreical }}: 6.39$ \\
\hline
\end{tabular}

${ }^{\mathrm{a}} \mathrm{g}$ per tablet; ${ }^{\mathrm{b}} \mathrm{mg} 100 \mathrm{~mL}^{-1}$; RSD: relative standard deviations. 


\section{Acknowledgements}

Financial supports of Süleyman Demirel University (Projects No. 1202-D-05) and Anadolu University (Project No. 031064) are gratefully acknowledged.

\section{References}

1. Ceresa, A.; Radu, A.; Peper, S.; Bakker, E.; Pretsch, E.; Anal. Chem. 2002, 74, 4027.

2. Sutter, J.; Radu, A.; Peper, S.; Bakker, E.; Pretsch, E.; Anal. Chim. Acta 2004, 523, 53.

3. Bakker, E.; Pretsch, E.; TrAC, Trends Anal. Chem. 2005, 24, 199.

4. Rubinova, N.; Chumbimuni-Torres, K.; Bakker, E.; Sens. Actuators, B 2007, 121, 135.

5. Szigeti, Z.; Malon, A.; Vigassy, T.; Csokai, V.; Grun, A.; Wygladacz, K.; Ye, N.; Xu, C.; Chebny, V. J.; Bitter, I.; Rathore, R.; Bakker, E.; Pretsch, E.; Anal. Chim. Acta 2006, 572, 1.

6. Nagels, L. J.; Poels, I.; TrAC, Trends Anal. Chem. 2000, 19, 410.

7. Poels, I.; Nagels, L. J.; Anal. Chim. Acta 2001, 440, 89.

8. Picioreanu, S.; Poels, I.; Frank, J.; Van Dam, J. C.; Van Dedem, G. W. K.; Nagels, L. J.; Anal. Chem. 2000, 72, 2029.

9. Bazylak, G.; Nagels, L. J.; J. Pharm. Biomed. Anal. 2003, 32, 887.

10. Bazylak, G.; Nagels, L. J.; Il Farmaco 2003, 58, 591.

11. Hibbert, D. B.; Jiang, J.; Mulholland, M.; Anal. Chim. Acta 2001, 443, 205.

12. De Backer, B. L.; Nagels, L. J; Alderweireldt, F. C.; Anal. Chim. Acta 1993, 273, 449.

13. Nagels, L. J.; Staes, E.; TrAC, Trends Anal. Chem. 2001, 20, 178.

14. Siangproh, W.; Dungchai, W.; Rattanarat, P.; Chailapakul, O.; Anal. Chim. Acta 2011, 690, 10.

15. Jemal, M.; Quing, Y.; Whigan, D. B.; Rapid Commun. Mass Spectrom. 1998, 12, 1389.

16. Vidal, J.C.; Garcia, E.; Castillo, J. R.; Anal. Chim. Acta 1999, 385,213
17. Şahin, M.; Şahin, Y.; Özcan, A.; Sens. Actuators, B 2008, 133, 5.

18. Stoev, G.; Michailova, A.; J. Chromatogr., A 2000, 871, 37.

19. Kishida, K.; Furusawa, N.; J. Chromatogr., A 2001, 937, 49.

20. Akay, C.; Özkan, S. A.; J. Pharm. Biomed. Anal. 2002, 30, 1207.

21. Garcia, I.; Sarabia, L.; Ortiz, M. C.; Aldama, J. M.; Analyst 2004, 129, 766.

22. Amini, H.; Ahmadiani, A.; J. Pharm. Biomed. Anal. 2007, 43, 1146.

23. Amin, A. S.; Shahat; M. F., Edeen; R. E., Meshref, M.; Anal. Lett. 2008, 41, 1878.

24. Shewigo, D. H.; Kaale, E.; Risha, P. G.; Dejaegher, B.; SmeyersVerbeke, J.; Vander Heyden, Y.; J. Chromatogr., A 2009, 1216, 7102 .

25. Klimes, J.; Mokry, M.; Pharmazie 1997, 52, 448.

26. Rao, T. N.; Sarada, B. V.; Tryk, D. A.; Fujishim, A.; J. Electroanal. Chem. 2000, 491, 175.

27. Preechaworapun, A.; Chuanuwatanakul, S.; Einaga, Y.; Grudpan, K.; Motomizu, S.; Chailapakul, O.; Talanta 2005, 68, 1726.

28. Galal, A.; Atta, N. F.; Rubinson, J. F.; Zimmer, H.; Mark, H. B.; Anal. Lett. 1993, 26, 1361.

29. Wang, J.; Jiang, M.; Mukherjee, B.; Anal. Chem. 1999, 71, 4095.

30. Riber, J.; Fuente, C.; Vazquez, M. D.; Tascon, M. L.; Batanero, P. S.; Talanta 2000, 52, 241.

31. Poels, I.; Nagels, L. J.; Verreyt, G.; Geise, H. J.; Biomed. Chromatogr. 1998, 12, 124.

32. Torres-Lapasio, J. R.; Garcia-Alvarez-Coque, M. C.; Bosch, E.; Roses, M.; J. Chromatogr., A 2005, 1089, 170.

33. Şanlı, N.; Şanlı, S.; Özkan, G.; Denizli, A.; J. Braz. Chem. Soc. 2010, 21, 1952.

34. Özkorucuklu, S. P.; Şahin, Y.; Alsancak, G.; Sensors 2008, 8, 8463.

Submitted: December 31, 2010 Published online: September 29, 2011 